\title{
Characteristics of triple-negative breast cancer
}

\author{
Tim C. de Ruijter · Jürgen Veeck • \\ Joep P. J. de Hoon • Manon van Engeland • \\ Vivianne C. Tjan-Heijnen
}

Received: 27 September 2010/Accepted: 20 October 2010/Published online: 11 November 2010

(C) The Author(s) 2010. This article is published with open access at Springerlink.com

\begin{abstract}
Background Triple-negative breast cancers (TNBC) neither express hormone receptors, nor overexpress HER2. They are associated with poor prognosis, as defined by low five-year survival and high recurrence rates after adjuvant therapy. Overall, TNBC share striking similarities with basal-like breast cancers (BBC), so a number of studies considered them being the same. The purpose of this review is to summarise the latest findings on TNBC concerning its relation and delineation to BBC, discuss the developmental pathways involved and address clinical implications for this complex type of breast cancer.

Methods The recent literature from PubMed and Medline databases was reviewed.

Results Not all TNBC are of the intrinsic BBC subtype (nonbasal (NB)-TNBC), nor are all BBC triple-negative (non-triple-negative (NTN)-BBC). There is increasing evidence that a triple-negative, basal-like breast cancer (TNBBC) subtype develops mainly through a BRCA1related pathway. Somatic mutations that contribute to NTN-BBC and NB-TNBC development are possibly not related to this pathway, but may occur randomly due to increased genomic instability in these tumours. Several
\end{abstract}

T. C. de Ruijter · J. Veeck - J. P. J. de Hoon .

V. C. Tjan-Heijnen ( $\square)$

Division of Medical Oncology, Department of Internal

Medicine, GROW School for Oncology and Developmental

Biology, Maastricht University Medical Centre, P.O. Box 5800, 6202 AZ Maastricht, The Netherlands

e-mail: vcg.tjan.heijnen@mumc.nl

T. C. de Ruijter · J. Veeck · J. P. J. de Hoon · M. van Engeland Department of Pathology, GROW School for Oncology and Developmental Biology, Maastricht University Medical Centre, Maastricht, The Netherlands therapeutic options exist for TNBBC, which exhibited promising results in recent clinical trials. Cytotoxic therapies, e.g. combined treatment with anthracyclines or taxanes, achieved good tumour regression rates in the neoadjuvant setting, but also showed considerable recurrence during the first 5 years after therapy. Targeted therapy options involve PARP1 and EGFR inhibition, although both approaches still need further investigation.

Conclusions TNBC and BBC are not the same disease entity. The TNBBC subtype shows the largest homogeneity in terms of tumour development, prognosis and clinical intervention options.

Keywords Triple-negative breast cancer (TNBC) . Basal-like breast cancer (BBC) - BRCA1 .

Adjuvant treatment Patient outcome

\section{Introduction}

Worldwide, 1.3 million women were estimated to be diagnosed with breast cancer in 2007 (Garcia et al. 2007) Therapeutic options for this type of cancer range from primary surgery to adjuvant chemotherapy, radiotherapy, hormonal therapy or targeted therapy. Breast cancer is a heterogeneous disease, and therefore, no golden standard therapy exists suitable for all tumours of the mammary gland (Early Breast Cancer Trialists' Collaborative Group 2005). For many years, tumours of the breast were characterised by tumour size only. However, this sub-classification proved to be limiting for it was unable to define subgroups sharing similar prognostic and therapeutic aspects. Later on, a histological classification system was developed, dividing breast cancer into subgroups distinguished by the histological appearance of the tumour. 
Despite advantages over the system based on tumour size alone, a histo-morphological subdivision also failed to form homogeneous breast cancer subgroups (Weigelt et al. 2008; Page 2003). Currently, the most widely used classification system of breast cancer combines histo-morphological information (such as histological subtype and grading) as well as TNM staging information, i.e. tumour size $(\mathrm{T})$ together with lymph node $(\mathrm{N})$ and distant metastasis occurrence (M) (Elston and Ellis 1993; Sobin et al. 2009). A more recent approach to classify breast cancer subgroups is that of gene expression profiling. Based on transcriptomic similarity, breast carcinomas can be distinguished as part of a group of five distinct breast cancer subtypes, of which the basal-like subtype is characterised by aggressive tumour growth and poorest patient survival (Sorlie et al. 2001, 2003).

Certain breast cancer treatment strategies, like hormonal therapy (e.g. anti-oestrogens) or targeted therapy (e.g. trastuzumab), are only effective when corresponding receptors and targets are expressed by the tumour cell. In breast cancer, a hormonal therapy requires oestrogen (ER) and/or progesterone receptor (PgR) expression to be effective, while trastuzumab therapy applies only to those tumours harbouring overexpression of HER2 due to amplification of its encoding oncogene ERBB2. Hormonal therapy and trastuzumab cause less adverse side effects when compared to chemotherapy and prolong disease-free survival (DFS) and overall survival (OS) of the patient (Samphao et al. 2009; Pienkowski and Zielinski 2010). However, some tumours neither express ER and PgR, nor do they overexpress HER2, for why these tumours were termed triple-negative breast cancer (TNBC). The prognosis of patients with this type of tumour is very poor, not only because hormonal therapy and treatment with trastuzumab are ruled out, but also because these tumours seem to be more aggressive than other breast carcinoma subtypes (Nofech-Mozes et al. 2009), similar to those of the basal-like breast cancer subtype.

The objective of this review is to summarise the latest findings on TNBC. It will address the following questions: What is the relation between the basal-like subtype and TNBC? What pathways are involved in the growth of these tumours? Do TNBC have a homogeneous gene expression profile? What is the prognosis of this kind of tumour? and What are the most effective forms of treatment?

\section{Triple negativity and the basal-like subtype of breast cancer}

Classically, breast carcinomas can be divided into 18 different subtypes based on histo-morphological characteristics (Tavassoli and Devilee 2003). A large majority of breast tumours (50-80\%) is designated as 'invasive ductal carcinoma not otherwise specified' (IDC NOS) (Weigelt et al. 2008). IDC NOS is defined as a tumour that fails to exhibit sufficient morphological features to be categorised as one of the other 17 subtypes (Page 2003; Tavassoli and Devilee 2003; Weigelt et al. 2008). Unfortunately, the histological way of categorising breast tumours fails to divide tumours into different entities of the disease with type-specific prognosis and treatment possibilities. In particular, the largest IDC NOS subtype shows an inhomogeneous prognosis (Weigelt et al. 2008). Moreover, the accuracy of histological classification depends greatly on the pathologist (Page 2003; Weigelt et al. 2008). A new approach to characterise breast tumours using molecular characteristics was first described by Sorlie et al. (2001). This study group clustered breast carcinomas based on similar gene expression profiles, as determined by DNA microarray experiments. The largest overall difference in gene expression was observed between hormone receptor (HR)-positive and HR-negative tumours. HR-positive tumours clustered in two groups with expression patterns similar to luminal epithelial mammary cells. HR-negative tumours clustered in three distinct molecular subgroups: tumours with gene expression similar to basal/myoepithelial mammary cells; tumours with characteristics of HER2 gene amplification; and tumours with expression patterns related to normal mammary stromal cells. The subtypes thus found are referred to as luminal A, luminal B, basallike, HER2-positive and normal-like breast cancer (Sorlie et al. 2001), all of which are associated with distinct prognosis and treatment possibilities. Interestingly, the normal-like breast carcinomas do not seem to constitute a true subtype. It is assumed that it represents breast cancer samples in which normal breast cells are overrepresented, suggesting that gene expression results reflect a non-cancer cell expression rather than that of the cancerous cells (Sorlie et al. 2001; Morris and Carey 2007).

Basal-like breast cancer (BBC) is associated with triple negativity of an ER/PgR/HER2 status (Sorlie et al. 2001). Therefore, several studies have used the absence of these receptors, sometimes along with cytokeratin $5 / 6$ or cytokeratin 17 expression, as a characteristic feature to define $\mathrm{BBC}$ in histological staining (Nielsen et al. 2004). However, a study by Bertucci et al. (2008) showed that TNBC and $\mathrm{BBC}$ are not the same entity. Using gene expression profiling, only 123 samples of the 172 triple-negative tumours $(71 \%)$ were determined to cluster with BBC, suggesting that not all TNBC are of the basal-like subtype. Reversely, only 123 (77\%) of the 160 tumours that were defined as BBC by gene expression profiling proved to be triple-negative in histological staining, indicating that not all BBC are triple-negative. In further studies, Morris et al. (2007) and Rakha et al. (2009) showed similar results. In 
addition, these studies showed that TNBC do not form a homogeneous group when analysed by gene expression profiling. In contrast, the basal-like subtype does form a homogeneous group of tumours with a similar gene expression profile related to prognosis and therapy response (Bertucci et al. 2008; Rakha et al. 2009). This indicates that the prognosis of TNBC may actually refer to the high percentage of triple-negative tumours that is of the basal-like subtype (Cheang et al. 2008). Indeed, several studies reported a poor disease-specific survival for the basal-like subtype (Sorlie et al. 2003; Nielsen et al. 2004; Carey et al. 2006; Morris et al. 2007). Furthermore, in cases in which metastasis occurred, the disease-free survival interval was found to be significantly shorter (Sorlie et al. 2003). Also, at primary diagnosis, basal-like tumours show adverse characteristics, such as a high nuclear and mitotic grade and unfavourable histological features, like high mitotic index and poor differentiation (Carey et al. 2006).

In conclusion, the triple-negative group of breast cancer is not a homogeneous disease entity. However, a substantial fraction of these tumours belongs to the basal-like tumour type, which does form a homogeneous group. Thus, the overall poor prognosis of TNBC may be a result of this basal-like subgroup, and triple negativity may be seen more as a symptom than as a separate entity of breast cancer.

\section{TNBC expression profiles and pathways leading to the triple-negative or basal-like subtype}

Although TNBC and BBC are not the same entity of the disease, there is a large overlap between them. As a consequence, many studies concerning gene expression and cellular pathways in the development of different subtypes of breast cancer do not distinguish between TNBC and $\mathrm{BBC}$. Moreover, evidence is present for a pathway that is related to the BRCA1 pathway that leads to the development of a basal-like, triple-negative subtype (TNBBC). This evidence will be discussed later on in this section. We propose a model in which non-basal-like TNBC (NBTNBC) and non-triple-negative BBC (NTN-BBC) are possibly not the direct result of this pathway, but receive their distinctive genotype because of random mutations. For example, if a breast tumour develops following disruption of the BRCA1-related pathway, it might turn into TNBBC. However, because of the instable genome, it is possible that genomic changes occur that are not BRCA1 pathway related (Fig. 1). If these genomic changes involve, for example, HER2 gene amplification, the tumour will no longer be TNBBC, but NTN-BBC. Since the tumour benefits from HER2 overexpression, there exists a selective pressure towards HER2 amplification. This could be the explanation for the approximately $20-30 \%$ of $\mathrm{BBC}$ that are not triple-negative. Likewise, in non-basal-like tumours, a selective pressure is present towards losing HR expression, since this enables the tumour to grow independently from the presence or absence of growth-stimulating factors. This may represent the cause of the approximately $20-30 \%$ of TNBC that are not of the basal-like subtype.

The three subgroups of TNBC and BBC show a different prognosis and imply distinct therapeutic options. Especially, NB-TNBC do not behave like TNBBC, for they show better prognosis despite less response to adjuvant chemotherapy (Rouzier et al. 2005; Rody et al. 2007; Tischkowitz et al. 2007). This is why in the remainder of this section of the review we will discuss the TNBBC subtype as defined by Sorlie et al. (2001).

TNBBCs have a specific expression profile that distinguishes them from other breast tumours, e.g. enhanced expression of $\mathrm{Ki}-67$, vimentin, laminin and p53, whereas expression of Bcl-2 is lower than in other subtypes (Rodriguez-Pinilla et al. 2007; Han et al. 2008). Several studies found expression of the tumour suppressor PTEN more frequently lost in TNBBC than in non-TNBC (Perren et al. 1999; Saal et al. 2008; Hu et al. 2009). PTEN plays a role in the phosphatidylinositol 3-kinase pathway, which is crucially involved in many breast cancer subtypes. Interestingly, if this pathway is affected in breast cancer, either PTEN or PIK3CA expression is lost, indicating that loss of one gene's activity may relieve the selective pressure on losing the other (Saal et al. 2005). Loss of PTEN expression is associated with a triple-negative phenotype, whereas downregulation of PIK3CA is associated with a triple-positive phenotype (Perren et al. 1999; Saal et al. $2005,2008)$. Other genes that tend to be mutated more frequently in TNBBC compared to other breast tumours are the tumour suppressor retinoblastoma gene $(R B I)$ and the $K R A S$ oncogene, both well known to enhance tumour growth (Hu et al. 2009).

Besides mutations, other genetic changes such as copy number alterations (CNA) occur differentially between distinct subtypes. Hu et al. (2009) observed that globally, CNA occur more often in TNBBC than in any other subtype. However, neither the functional impact of these lesions nor the frequency at which one specific CNA occurred could match those of the HER $2+$ subtype. In more than $30 \%$ of the TNBBC cases, two specific CNA are found, i.e. gene amplification and chromosomal deletion (Han et al. 2008; Hu et al. 2009). A gene that was found to be specifically amplified in TNBBC is nuclear factor $1 / \mathrm{B}$ $(N F I B)$, residing on the short arm of chromosome 9 . The function of this gene in cancer biology has to be defined yet; however, it plays a known role in central nervous system development (Han et al. 2008; Mason et al. 2009). A structural deletion of $80 \mathrm{Mb}$ on chromosome 5q13-14 
Fig. 1 Origin and related pathways of different types of triple-negative and basal-like breast tumours. The non-basallike triple-negative breast cancers (NB-TNBC) may originate from non-basal-like breast cancer (N-BBC), and the non-triple-negative basal-like breast cancer (NTN-BBC) as well as triple-negative basal-like breast cancers (TNBBC) may originate from basal-like breast cancers (BBC). Only the TNBBC subtype can be regarded as a homogeneous breast cancer subgroup

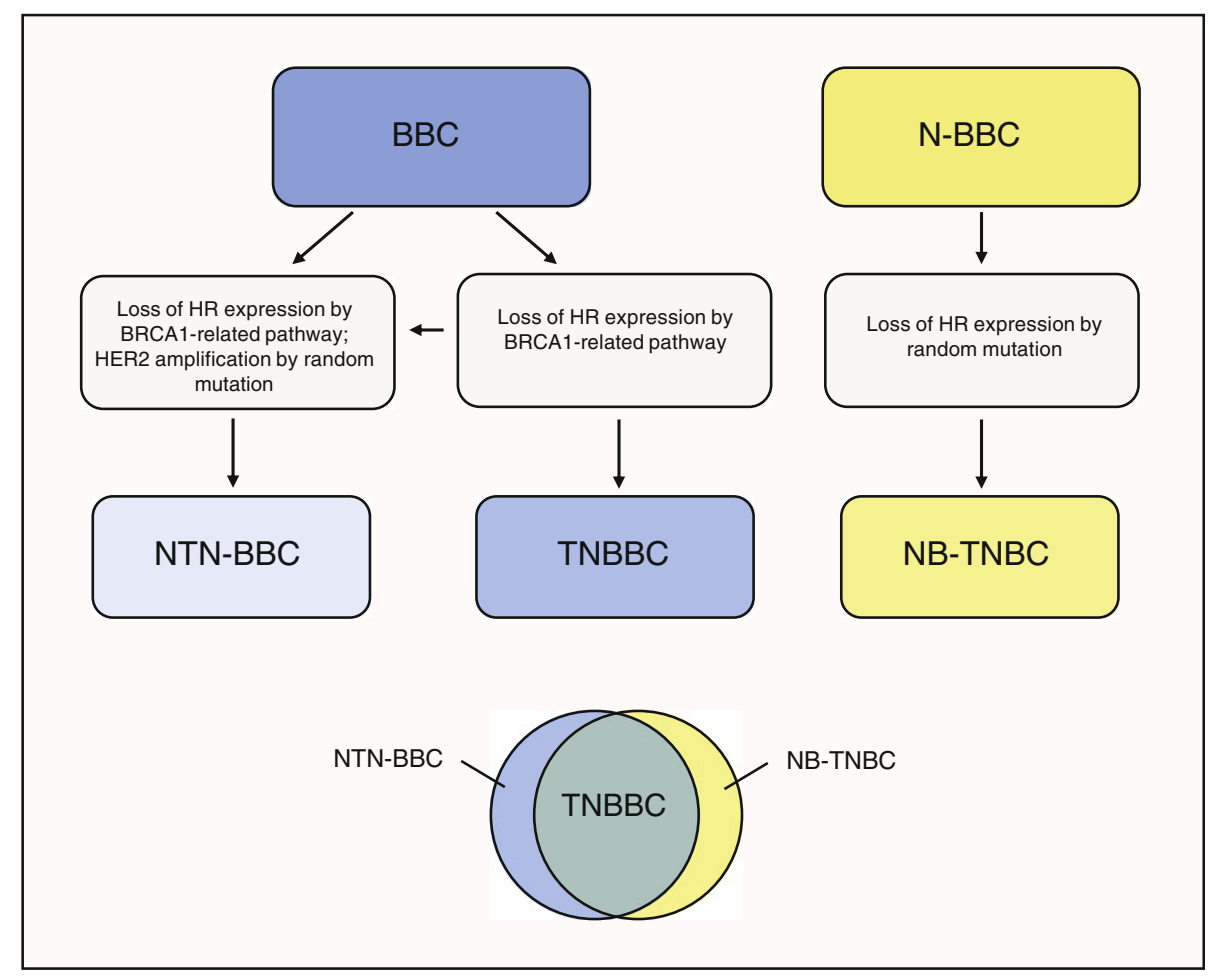

that occurs more frequently in TNBC contains the RASAI gene. This gene has a function in de-activating RAS, and loss of RASAl results in an overactive RAS tyrosine kinase. Since RAS is a stimulator of cell growth, RAS overactivation leads to increased proliferation activity $(\mathrm{Hu}$ et al. 2009). NFIB and RASAl are not the only genes playing a key role in tumorigenesis by CNA. A study comparing gene expression signatures reflecting chromosomal instability with signatures of the different breast cancer subtypes revealed that TNBBC, along with the HER2 + subgroup, displays the most instable genome. They also found that mutations in the PTEN and RBI gene are associated with this chromosomal instability ( $\mathrm{Hu}$ et al. 2009).

In search of pathways that lead to the development of TNBBC, several studies have found that BRCA1-related breast cancers are associated with the TNBBC subtype (Foulkes et al. 2003; Lakhani et al. 2005; Diaz et al. 2007), and TNBBC expression profiles resemble those of BRCA1related breast cancers (Foulkes et al. 2003). This resemblance gave rise to the idea that $B R C A 1$ mutations could play a role in the development of TNBBC. Further findings support this idea. For example, the earlier mentioned deletion in chromosome $5 \mathrm{q}$ found in TNBBC is also associated with BRCA1-related breast cancer, occurring in $71 \%$ of cases (Johannsdottir et al. 2006; Hu et al. 2009). Moreover, abnormalities in the inactive $\mathrm{X}$ chromosome (Xi) that destabilise its silenced state and activate genes that are inactive in non-cancerous cells are associated with loss of
BRCA1 function (Ganesan et al. 2002), and they are also associated with TNBBC (Richardson et al. 2006; Turner et al. 2007). Taken together, these findings support the hypothesis that loss of BRCA1 function may play a major role in TNBBC development (Richardson et al. 2006).

Since not all TNBBC harbour mutations in BRCAl, it appears that it is not structural mutations alone to be necessary for the development of TNBBC. Several studies have investigated epigenetic changes, such as DNA methylation, influencing the expression of BRCA1 in TNBBC. However, DNA methylation does not seem to play a supportive role, since $B R C A 1$ methylation occurs similar frequent in TNBBC and non-TNBBC (Turner et al. 2007; Matros et al. 2005). In contrast, Turner et al. (2007) compared BRCA1 expression in TNBBC to BRCA1 expression in other tumour types and found that expression in TNBBC was twofold lower. In addition, the expression levels of inhibitor of DNA binding 4 (ID4), representing a negative regulator of BRCA1 (Beger et al. 2001), proved to be ninefold higher in TNBBC (Turner et al. 2007). This implies that low BRCA1 expression could also be the result of gene regulatory mechanisms, such as ID4 overexpression in these tumours. Still, the fact that not all TNBBC show loss of BRCA1 expression suggests that further genes related to the BRCA1 pathway are likely to be deregulated in the process of TNBBC development (Richardson et al. 2006).

Several studies linked TNBBC to epidermal growth factor receptor (EGFR) expression, and percentages 
ranging from 42 to $71 \%$ were found (Nielsen et al. 2004; Nalwoga et al. 2008; Cheang et al. 2008; Meche et al. 2009; Collins et al. 2009). This receptor, like HER2, is a potent stimulating factor of cell-growth-activating pathways and thus stimulates tumour growth when activated (Burgess 2008). EGFR expression in breast cancer is associated with poor disease outcome. Viale et al. (2009) showed worse disease-free survival (DFS), overall survival (OS) and distant disease-free survival (DDFS) for EGFR expressing TNBBC compared to tumours without EGFR expression. Also, response rates of EGFR-positive breast tumours to chemotherapeutic therapy proved to be lower (Nogi et al. 2009). EGFR expression could be one of the causes of the poor disease outcome of TNBBC. Since EGFR can be targeted by newly developed therapies, assessment of EGFR expression, like commonly performed on HER2, could have major therapeutic relevance, as will be described later in this review (Stratford et al. 2007; Hoadley et al. 2007).

\section{Prognostic implications of triple-negative breast cancer}

Since most prognostic research is performed as retrospective studies, many of these studies use data collected for diagnostic reasons. Mostly, these studies do not investigate markers for basal-like breast cancer and use triple negativity as an inclusion factor to select their study population. This is why in the following section prognosis is being discussed for TNBC, rather than specifically for TNBBC.

Patients with TNBC suffer from poor prognosis (Nofech-Mozes et al. 2009). Compared to other breast cancer subtypes, TNBC develop earlier in life, and consequently more often in pre-menopausal women (Carey et al. 2006; Rhee et al. 2008). At diagnosis, TNBCs are commonly of high nuclear mitotic grade, of larger tumour size, and they show a more aggressive expression profile with low Bcl-2 but high p53 and Ki67 expression (Foulkes et al. 2004; Fulford et al. 2006; Tian et al. 2008; Dogan et al. 2008; Nishimura and Arima 2008; Chivukula et al. 2008). Taken together, these adverse factors may be a major reason for poorer OS, breast-cancer-specific survival (BCSS) and relapse-free survival (RFS) reported for this disease. Several studies demonstrated significantly lower RFS in patients with TNBC compared to patients with non-TNBC. Rhee et al. found that the four-year survival of TNBC patients was $85.5 \%$, compared to $94.2 \%$ in non-TNBC patients (Rhee et al. 2008). Parikh et al. (2008) showed that the frequency of relapse is less favourable in TNBC. Also, the median time to tumour recurrence proved to be 1.2 years shorter in patients with TNBC when compared to non-TNBC patients. Likewise in recurrent breast cancer, those patients with TNBC still had a worse prognosis than
non-TNBC. Not only the risk of tumour recurrence was higher, but also the risk of dying as a consequence of this relapse. Mersin et al. (2008) reported a hazard ratio of 4.2 for developing tumour recurrence for TNBC when compared to non-TNBC. Similar results for RFS in TNBC are widely reported (Sorlie et al. 2003; Rakha et al. 2007; Dent et al. 2007; Tian et al. 2008; Nishimura and Arima 2008; Kaplan and Malmgren 2008). Overall five-year survival was determined to be $81 \%$ for TNBC compared to $91 \%$ for triple-positive breast cancer, and 94\% for HR-positive/ HER2-negative (HR+/HER2-) breast cancer (Kaplan and Malmgren 2008). Like RFS, shorter OS in TNBC is widely reported (Dent et al. 2007; Tian et al. 2008; Nishimura and Arima 2008; Chivukula et al. 2008). There is only one breast cancer subtype that has a prognosis comparably poor as TNBC. This is the HR-negative, HER2-positive (HR-/ HER2+) subtype. BCSS of this subgroup is reported as $86 \%$, compared to $88 \%$ in the TNBC subgroup and $95 \%$ in the triple-positive group (Kaplan and Malmgren 2008). However, it should be noted that the recently published long-term studies on breast cancer survival mostly included patients during the pre-trastuzumab era. The introduction of trastuzumab as therapy regimen significantly improved the prognosis in the HR-/HER2+ subgroup (Pienkowski and Zielinski 2010). Interestingly, it seems that the higher risks of recurrence and tumour-related death diminish over time. After 5 years of therapy, each type of risk is lowered and almost equals those of the non-TNBC subtypes (Dent et al 2007; Hergueta-Redondo et al. 2008). This suggests that the poor prognosis of TNBC may be due to effects that occur during the first 5 years after surgery.

\section{Therapeutic options of triple-negative breast cancer}

In general, adjuvant therapeutic options for TNBBC can be divided into two groups, cytotoxic agents and targeted therapies. Cytotoxic agents confer a DNA-damaging effect to generally all dividing cells. Fast dividing cells, like cancer cells, are more susceptible to cytotoxic therapy, but so are other fast dividing normal cells, like blood cells. This is why cytotoxic agents often result in numerous adverse side effects. In contrast, targeted therapies interfere with a specific biomolecule to which their effect is directed. This target is a specific characteristic of the cancerous cell, e.g. an overexpressed receptor, providing certain selectivity against malignant cells, thereby being ineffective or less effective on normal cells (Tan and Swain 2008).

The short-term effects of cytotoxic agents are greater in TNBBC than in any other breast cancer subtype (Carey et al. 2007). Patients with TNBBC have increased pathologic complete response (pCR) rates compared to nonTNBC patients, especially to taxanes and anthracycline 
agents (Carey et al. 2007; Hugh et al. 2009). Wang et al. (2009) found a pCR of $38 \%$ in TNBBCs, compared to $14 \%$ in non-TNBBCs when treated with taxane in combination with anthracycline agents. Similar results were found by Liedtke et al. (2008). In spite of the better response to chemotherapy, the prognosis of TNBBC is still worse than that of other breast cancer subtypes, due to a higher likelihood of relapse in patients with residual disease (Rouzier et al. 2005; Dent et al. 2007; Carey et al. 2007).

Another group of cytotoxic agents showing good results in TNBBC are the platinum-containing agents, such as cisplatin and carboplatin (Tan and Swain 2008). To date, only few studies on the effect of these platinum-containing agents in TNBBC have been completed. One study by Sirohi et al. (2008) reported a clinical response rate of $88 \%$ in TNBBC after neo-adjuvant treatment with platinumcontaining cytotoxic agents, compared to $55 \%$ clinical complete response rate in other breast tumours. However, the overall five-year survival was still worse for TNBBC compared to tumours of other subtypes.

Targeted therapies are currently being developed or evaluated for TNBBC, including inhibition of Poly [ADPribose] polymerase 1 (PARP1) and EGFR, the latter also known as HER1. However, none of these therapies have yet reached approval level by the US. Food and Drug Administration (FDA) (Tan and Swain 2008). PARP1 is an enzyme that has an important function in the repair of DNA single-strand breaks (SSB) as a part of the base excision repair pathway (Dantzer et al. 2000). In this pathway, PARP1 binds to the exposed ends of the corrupted DNA strand and recruits essential enzymes needed to repair SSBs. When PARP1 is inhibited, the base excision repair pathway fails, which leads to accumulation of SSBs. In a replicating cell entering the $S$-phase, replication is arrested at a SSB site, leading to a DNA double-strand break (DSB).

Inhibition of PARP1 leads to more single-strand breaks in all cells, so why is it a targeted therapy? In healthy cells, DSBs lead to the activation of a repair mechanism referred to as homologous recombination. Since homologous recombination uses an intact DNA strand as a template, this mechanism is accurate and error-free. An important mediator in this pathway is BRCA1. In the absence of BRCA1, DSBs cannot be repaired by homologous recombination, and cells activate an alternative repair pathway termed non-homologous end joining (NHEJ). Intriguingly, NHEJ is highly error-prone. Thus, in BRCA1-deficient cells, the damage executed by PARP inhibitors leads to accumulation of structural DNA lesions, which results in genomic instability and finally apoptotic cell death. Since BRCA2 operates in the same pathway like BRCA1, deficiency of this protein renders the cell vulnerable to PARP inhibitors as well (D'Amours et al. 1999; Tutt and
Ashworth 2002). Preclinical in vivo models investigating the effectiveness of PARP inhibitors in the triple-negative/ basal-like setting have shown significant tumour regression, longer DFS and OS in mice (Rottenberg et al. 2008). When applying a dose non-cytotoxic for healthy cells in mouse models carrying a BRCA2 mutation, similar effects were achieved (Kyle et al. 2008; Hay et al. 2009). Recently, several phase I and phase II trials of PARP inhibitors have been performed with BRCAl mutation carriers, showing promising anti-tumour activity and only few adverse side effects. For instance, in a phase I trial, the PARP inhibitor olaparib (AZD2281) showed selective activity against $B R C A 1 / 2$-mutated breast cancer, whereas BRCA-unrelated tumours remained unaffected (Fong et al. 2009). Based on this finding, Tutt et al. (2010) demonstrated in a phase II trial on efficacy, safety and tolerability employing solely $B R C A 1 / 2$ mutation carriers that olaparib at a higher dose was also associated with an improved objective response rate, while toxicity in BRCA1/2 mutation carriers was similar low to that reported for patients without BRCA mutations. In a further randomised phase II trial, another PARP inhibitor, BSI-201, showed significantly increased OS in combination with gemcitabine and carboplatin when compared to the standard regimen alone, in heavily pre-treated patients. Importantly, this trial recruited TNBC only and showed in parallel that TNBC also exhibited significantly elevated PARP1 expression levels in contrast to normal breast tissue (O'Shaughnessy et al. 2008). An important question here is that of how to select the right patient population among TNBC subtypes most likely to respond to inhibition of PARP. Addressing this question, several scenarios have recently evolved. As previously mentioned, BRCA1/2 genotyping may be beneficial, as these tumours affected by mutation show large overlap with the TNBC phenotype. In another study, TNBC were shown to express PARP1 more frequently than other breast cancer subtypes (von Minckwitz et al. 2010). High levels of PARP1 expression also correlated with improved response to chemotherapy, so it is intriguing to see whether levels of PARP1 expression may also predict response to olaparib or BSI-201 in combination with conventional chemotherapy, a trial that is currently being initiated by the respective study group (von Minckwitz et al. 2010). Third, other disruptions of DNA damage repair may also contribute to PARP inhibitor sensitivity. For instance, gene inactivation by promoter methylation of $B R C A l$ is a common lesion among sporadic breast tumours (Esteller et al. 2000). Interestingly, BRCAl-methylated and BRCAlmutated breast cancers exhibit similar transcriptional profiles (Hedenfalk et al. 2001). A recent study revealed that the frequency of BRCAl methylation is elevated among TNBC, and the inhibition of PARP in BRCAl-methylated breast cancer cell lines is similar effective as in BRCAl- 
mutated cell lines (Veeck et al. 2010), altogether suggesting that also BRCAl-methylated sporadic breast cancers might be susceptible to PARP inhibitors. In summary, further parameters may become valuable biomarkers of PARP inhibitor response among patients with TNBC. These parameters should be assessed in current and ongoing future trials as stratifying biomarkers of response among TNBC in order to identify the population with the greatest benefit of this kind of treatment. Despite these promising findings, Edwards et al. discovered resistance to PARP inhibitors developing in tumour cells as a result of a deletion in BRCA2, reactivating the disabled gene (Edwards et al 2008). Besides from using PARP inhibitors as (neo)adjuvant therapy, it has been suggested as a preventive strategy. In patients with an inherited BRCA1/2 mutation, preventive use of PARP inhibitors may eliminate any cell developing a second $B R C A 1 / 2$ hit, before it advances further to cancer (Helleday et al. 2005). More research on the long-term effects of PARP inhibitor use needs to be performed before preventive use of PARP inhibitors can be considered.

As described earlier, TNBBC is more likely to express EGFR than other breast cancer subtypes (Nielsen et al. 2004; Cheang et al. 2008; Meche et al. 2009; Collins et al. 2009; Nalwoga et al. 2008). The EGF receptor stimulates cell replication similar to HER2. If targeted, the stimulating effect of EGFR could be diminished, resulting in tumour growth arrest or even tumour regression. EGFR can be targeted by two types of agents, monoclonal antibodies (mAbs) and small molecule tyrosine kinase inhibitors (TKIs). MAbs target the extracellular domain of the receptor, inhibiting its function by blocking ligand binding and receptor internalisation. Possibly, they can also trigger an immune reaction against the EGFR expressing cell. TKIs target the intracellular domain of the receptor, inhibiting its tyrosine kinase activity and rendering the receptor impotent (Harari 2004). Corkery et al. (2009) evaluated the effect of the TKI gefitinib in combination with docetaxel on TNBC cell lines and found higher effectiveness of the combined therapy scheme. However, as a monotherapy gifitinib seems to be ineffective, since phase II studies showed very little benefit from gifitinib monotherapy in hormone resistant breast tumours (Green et al. 2009; von Minckwitz et al. 2005). Unfortunately, results for another TKI, lapatinib, were as disappointing by showing very little clinical benefit, except for HER2positive tumours (Burris et al. 2009). Other phase II studies addressing the effectiveness of the monoclonal EGFR antibody cetuximab are currently being performed. It seems that inhibition of EGFR as a monotherapy is ineffective, but it can increase the effectiveness of adjuvant chemotherapy (Oliveras-Ferraros et al. 2008). Cetuximab has already been approved for use in metastatic colon cancer. However, results in breast cancer are not yet convincing for either TKIs or mAbs (Burness et al. 2010); thus, more research is needed to study their potential benefits and improve their effectiveness.

\section{Conclusions}

Triple-negative breast tumours show high recurrence and poor survival rates. Often, TNBC and BBC are assumed to represent similar entities. In fact, TNBC and BBC share certain similarities but are clearly not identical entities of breast cancer. There is increasing evidence that points towards a BRCA1-related pathway leading to the development of a TNBBC subtype. Possibly, TNBBC develops due to aberrations in this BRCA1-related pathway, whereas mutations that are not related to this pathway may occur randomly because of the genomic instability of the tumour and may lead to NTN-BBC and NB-TNBC subtypes. TNBBC shows a good initial response to chemotherapeutic agents, especially to anthracyclines and taxanes. However, in the neo-adjuvant setting, recurrence rates after pathologic complete response are high. Targeted therapies, like PARP inhibitors and EGFR targeting agents, might represent further promising therapeutic options, but still need to be evaluated in appropriate phase III clinical trials.

Conflict of interest The authors declare no potential conflicts of interest with respect to the authorship and/or publication of this article.

Open Access This article is distributed under the terms of the Creative Commons Attribution Noncommercial License which permits any noncommercial use, distribution, and reproduction in any medium, provided the original author(s) and source are credited.

\section{References}

Beger C, Pierce LN, Kruger M, Marcusson EG, Robbins JM, Welcsh P, Welch PJ, Welte K, King MC, Barber JR, Wong-Staal F (2001) Identification of Id4 as a regulator of BRCA1 expression by using a ribozyme-library-based inverse genomics approach. Proc Natl Acad Sci USA 98:130-135

Bertucci F, Finetti P, Cervera N, Esterni B, Hermitte F, Viens P, Birnbaum D (2008) How basal are triple-negative breast cancers? Int J Cancer 123:236-240

Burgess AW (2008) EGFR family: structure physiology signalling and therapeutic targets. Growth Factors 26:263-274

Burness ML, Grushko TA, Olopade OI (2010) Epidermal growth factor receptor in triple-negative and basal-like breast cancer: promising clinical target or only a marker? Cancer J 16:23-32

Burris HA III, Taylor CW, Jones SF, Koch KM, Versola MJ, Arya N, Fleming RA, Smith DA, Pandite L, Spector N, Wilding G (2009) A phase I and pharmacokinetic study of oral lapatinib administered once or twice daily in patients with solid malignancies. Clin Cancer Res 15:6702-6708 
Carey LA, Perou CM, Livasy CA, Dressler LG, Cowan D, Conway K, Karaca G, Troester MA, Tse CK, Edmiston S, Deming SL, Geradts J, Cheang MC, Nielsen TO, Moorman PG, Earp HS, Millikan RC (2006) Race, breast cancer subtypes, and survival in the Carolina Breast Cancer Study. JAMA 295:2492-2502

Carey LA, Dees EC, Sawyer L, Gatti L, Moore DT, Collichio F, Ollila DW, Sartor CI, Graham ML, Perou CM (2007) The triple negative paradox: primary tumor chemosensitivity of breast cancer subtypes. Clin Cancer Res 13:2329-2334

Cheang MC, Voduc D, Bajdik C, Leung S, McKinney S, Chia SK, Perou CM, Nielsen TO (2008) Basal-like breast cancer defined by five biomarkers has superior prognostic value than triplenegative phenotype. Clin Cancer Res 14:1368-1376

Chivukula M, Striebel JM, Ersahin C, Dabbs DJ (2008) Evaluation of morphologic features to identify "basal-like phenotype" on core needle biopsies of breast. Appl Immunohistochem Mol Morphol $16: 411-416$

Collins LC, Martyniak A, Kandel MJ, Stadler ZK, Masciari S, Miron A, Richardson AL, Schnitt SJ, Garber JE (2009) Basal Cytokeratin and epidermal growth factor receptor expression are not predictive of BRCA1 mutation status in women with triple-negative breast cancers. Am J Surg Pathol 33:1093-1097

Corkery B, Crown J, Clynes M, O’Donovan N (2009) Epidermal growth factor receptor as a potential therapeutic target in triplenegative breast cancer. Ann Oncol 20:862-867

D’Amours D, Desnoyers S, D'Silva I, Poirier GG (1999) Poly(ADPribosyl)ation reactions in the regulation of nuclear functions. Biochem J 342:249-268

Dantzer F, de La Rubia G, Menissier-De Murcia J, Hostomsky Z, de Murcia G, Schreiber V (2000) Base excision repair is impaired in mammalian cells lacking Poly(ADP-ribose) polymerase-1. Biochemistry 39:7559-7569

Dent R, Trudeau M, Pritchard KI, Hanna WM, Kahn HK, Sawka CA, Lickley LA, Rawlinson E, Sun P, Narod SA (2007) Triplenegative breast cancer: clinical features and patterns of recurrence. Clin Cancer Res 13:4429-4434

Diaz LK, Cryns VL, Symmans WF, Sneige N (2007) Triple negative breast carcinoma and the basal phenotype: from expression profiling to clinical practice. Adv Anat Pathol 14:419-430

Dogan L, Atalay C, Yilmaz KB, Ozaslan C (2008) Prognosis in hormon receptor negative breast cancer patients according to ERBB2 status. Neoplasma 55:544-548

Early Breast Cancer Trialists' Collaborative Group (EBCTCG) (2005) Effects of chemotherapy and hormonal therapy for early breast cancer on recurrence and 15-year survival: an overview of the randomised trials. Lancet 365:1687-1717

Edwards SL, Brough R, Lord CJ, Natrajan R, Vatcheva R, Levine DA, Boyd J, Reis-Filho JS, Ashworth A (2008) Resistance to therapy caused by intragenic deletion in BRCA2. Nature 451:1111-1115

Elston EW, Ellis IO (1993) Method for grading breast cancer. J Clin Pathol 46:189-190

Esteller M, Silva JM, Dominguez G, Bonilla F, Matias-Guiu X, Lerma E, Bussaglia E, Prat J, Harkes IC, Repasky EA, Gabrielson E, Schutte M, Baylin SB, Herman JG (2000) Promoter hypermethylation and BRCA1 inactivation in sporadic breast and ovarian tumors. J Natl Cancer Inst 92:564-569

Fong PC, Boss DS, Yap TA, Tutt A, Wu P, Mergui-Roelvink M, Mortimer P, Swaisland H, Lau A, O'Connor MJ, Ashworth A, Carmichael J, Kaye SB, Schellens JH, de Bono JS (2009) Inhibition of poly(ADP-ribose) polymerase in tumors from BRCA mutation carriers. N Engl J Med 361:123-134

Foulkes WD, Stefansson IM, Chappuis PO, Begin LR, Goffin JR, Wong N, Trudel M, Akslen LA (2003) Germline BRCA1 mutations and a basal epithelial phenotype in breast cancer. J Natl Cancer Inst 95:1482-1485
Foulkes WD, Brunet JS, Stefansson IM, Straume O, Chappuis PO, Begin LR, Hamel N, Goffin JR, Wong N, Trudel M, Kapusta L, Porter P, Akslen LA (2004) The prognostic implication of the basal-like (cyclin E high/p27 low/p53+/glomeruloid-microvascular-proliferation+) phenotype of BRCA1-related breast cancer. Cancer Res 64:830-835

Fulford LG, Easton DF, Reis-Filho JS, Sofronis A, Gillett CE, Lakhani SR, Lakhani SR, Hanby A (2006) Specific morphological features predictive for the basal phenotype in grade 3 invasive ductal carcinoma of breast. Histopathology 49:22-34

Ganesan S, Silver DP, Greenberg RA, Avni D, Drapkin R, Miron A, Mok SC, Randrianarison V, Brodie S, Salstrom J, Rasmussen TP, Klimke A, Marrese C, Marahrens Y, Deng CX, Feunteun J, Livingston DM (2002) BRCA1 supports XIST RNA concentration on the inactive $X$ chromosome. Cell 111:393-405

Garcia M, Jemal A, Ward EM, Center MM, Hao Y, Siegel RL, Thun MJ (2007) Global cancer facts \& figures 2007. American Cancer Society, Atlanta, GA

Green MD, Francis PA, Gebski V, Harvey V, Karapetis C, Chan A, Snyder R, Fong A, Basser R, Forbes JF, Australian New Zealand Breast Cancer Trials Group (2009) Gefitinib treatment in hormone-resistant and hormone receptor-negative advanced breast cancer. Ann Oncol 20:1813-1817

Han W, Jung EM, Cho J, Lee JW, Hwang KT, Yang SJ, Kang JJ, Bae JY, Jeon YK, Park IA, Nicolau M, Jeffrey SS, Noh DY (2008) DNA copy number alterations and expression of relevant genes in triple-negative breast cancer. Genes Chromosomes Cancer 47:490-499

Harari PM (2004) Epidermal growth factor receptor inhibition strategies in oncology. Endocr Relat Cancer 11:689-708

Hay T, Matthews JR, Pietzka L, Lau A, Cranston A, Nygren AO, Douglas-Jones A, Smith GC, Martin NM, O'Connor M, Clarke AR (2009) Poly(ADP-ribose) polymerase-1 inhibitor treatment regresses autochthonous Brca2/p53-mutant mammary tumors in vivo and delays tumor relapse in combination with carboplatin. Cancer Res 69:3850-3855

Hedenfalk I, Duggan D, Chen Y, Radmacher M, Bittner M, Simon R, Meltzer P, Gusterson B, Esteller M, Kallioniemi OP, Wilfond B, Borg A, Trent J, Raffeld M, Yakhini Z, Ben-Dor A, Dougherty E, Kononen J, Bubendorf L, Fehrle W, Pittaluga S, Gruvberger S, Loman N, Johannsson O, Olsson H, Sauter G (2001) Geneexpression profiles in hereditary breast cancer. $\mathrm{N}$ Engl $\mathrm{J}$ Med 344:539-548

Helleday T, Bryant HE, Schultz N (2005) Poly(ADP-ribose) polymerase (PARP-1) in homologous recombination and as a target for cancer therapy. Cell Cycle 4:1176-1178

Hergueta-Redondo M, Palacios J, Cano A, Moreno-Bueno G (2008) "New" molecular taxonomy in breast cancer. Clin Transl Oncol 10:777-785

Hoadley KA, Weigman VJ, Fan C, Sawyer LR, He X, Troester MA, Sartor CI, Rieger-House T, Bernard PS, Carey LA, Perou CM (2007) EGFR associated expression profiles vary with breast tumor subtype. BMC Genomics 8:258

Hu X, Stern HM, Ge L, O'Brien C, Haydu L, Honchell CD, Haverty PM, Peters BA, Wu TD, Amler LC, Chant J, Stokoe D, Lackner MR, Cavet G (2009) Genetic alterations and oncogenic pathways associated with breast cancer subtypes. Mol Cancer Res 7:511-522

Hugh J, Hanson J, Cheang MC, Nielsen TO, Perou CM, Dumontet C, Reed J, Krajewska M, Treilleux I, Rupin M, Magherini E, Mackey J, Martin M, Vogel C (2009) Breast cancer subtypes and response to docetaxel in node-positive breast cancer: use of an immunohistochemical definition in the BCIRG 001 trial. J Clin Oncol 27:1168-1176

Johannsdottir HK, Jonsson G, Johannesdottir G, Agnarsson BA, Eerola H, Arason A, Heikkila P, Egilsson V, Olsson H, 
Johannsson OT, Nevanlinna H, Borg A, Barkardottir RB (2006) Chromosome 5 imbalance mapping in breast tumors from BRCA1 and BRCA2 mutation carriers and sporadic breast tumors. Int J Cancer 119:1052-1060

Kaplan HG, Malmgren JA (2008) Impact of triple negative phenotype on breast cancer prognosis. Breast J 14:456-463

Kyle S, Thomas HD, Mitchell J, Curtin NJ (2008) Exploiting the Achilles heel of cancer: the therapeutic potential of poly(ADPribose) polymerase inhibitors in BRCA2-defective cancer. Br J Radiol 81(Spec No 1):6-11

Lakhani SR, Reis-Filho JS, Fulford L, Penault-Llorca F, van der Vijver M, Parry S, Bishop T, Benitez J, Rivas C, Bignon YJ, Chang-Claude J, Hamann U, Cornelisse CJ, Devilee P, Beckmann MW, Nestle-Krämling C, Daly PA, Haites N, Varley J, Lalloo F, Evans G, Maugard C, Meijers-Heijboer H, Klijn JG, Olah E, Gusterson BA, Pilotti S, Radice P, Scherneck S, Sobol H, Jacquemier J, Wagner T, Peto J, Stratton MR, McGuffog L, Easton DF, Breast Cancer Linkage Consortium (2005) Prediction of BRCA1 status in patients with breast cancer using estrogen receptor and basal phenotype. Clin Cancer Res 11:5175-5180

Liedtke C, Mazouni C, Hess KR, Andre F, Tordai A, Mejia JA, Symmans WF, Gonzalez-Angulo AM, Hennessy B, Green M, Cristofanilli M, Hortobagyi GN, Pusztai L (2008) Response to neoadjuvant therapy and long-term survival in patients with triple-negative breast cancer. J Clin Oncol 26:1275-1281

Mason S, Piper M, Gronostajski RM, Richards LJ (2009) Nuclear factor one transcription factors in CNS development. Mol Neurobiol 39:10-23

Matros E, Wang ZC, Lodeiro G, Miron A, Iglehart JD, Richardson AL (2005) BRCA1 promoter methylation in sporadic breast tumors: relationship to gene expression profiles. Breast Cancer Res Treat 91:179-186

Meche A, Cimpean AM, Raica M (2009) Immunohistochemical expression and significance of epidermal growth factor receptor (EGFR) in breast cancer. Rom J Morphol Embryol 50:217-221

Mersin H, Yildirim E, Berberoglu U, Gulben K (2008) The prognostic importance of triple negative breast carcinoma. Breast $17: 341-346$

Morris SR, Carey LA (2007) Gene Expression profiling in Breast Cancer. Curr Opin Oncol 19:547-551

Morris GJ, Naidu S, Topham AK, Guiles F, Xu Y, McCue P, Schwartz GF, Park PK, Rosenberg AL, Brill K, Mitchell EP (2007) Differences in breast carcinoma characteristics in newly diagnosed African-American and Caucasian patients: a singleinstitution compilation compared with the National Cancer Institute's Surveillance, Epidemiology, and End Results database. Cancer 110:876-884

Nalwoga H, Arnes JB, Wabinga H, Akslen LA (2008) Expression of EGFR and c-kit is associated with the basal-like phenotype in breast carcinomas of African women. APMIS 116:515-525

Nielsen TO, Hsu FD, Jensen K, Cheang M, Karaca G, Hu Z, Hernandez-Boussard T, Livasy C, Cowan D, Dressler L, Akslen LA, Ragaz J, Gown AM, Gilks CB, van de Rijn M, Perou CM (2004) Immunohistochemical and clinical characterization of the basal-like subtype of invasive breast carcinoma. Clin Cancer Res 10:5367-5374

Nishimura R, Arima N (2008) Is triple negative a prognostic factor in breast cancer? Breast Cancer 15:303-308

Nofech-Mozes S, Trudeau M, Kahn HK, Dent R, Rawlinson E, Sun P, Narod SA, Hanna WM (2009) Patterns of recurrence in the basal and non-basal subtypes of triple-negative breast cancers. Breast Cancer Res Treat 118:131-137

Nogi H, Kobayashi T, Suzuki M, Tabei I, Kawase K, Toriumi Y, Fukushima H, Uchida K (2009) EGFR as paradoxical predictor of chemosensitivity and outcome among triple-negative breast cancer. Oncol Rep 21:413-417
O’Shaughnessy J, Osborne C, Pippen J, Yoffe M, Patt D, Monaghan G, Rocha C, Ossovskaya V, Sherman B, Bradley C (2008) Efficacy of BSI-201. A poly (ADP-ribose) polymerase (PARP1) inhibitor, in combination with gemcitamine/carboplatin in patients with metastatic triple negative breast cancer: results of a randomized phase II trial. J Clin Oncol 26: May 20 suppl; abstr 1015

Oliveras-Ferraros C, Vazquez-Martin A, Lopez-Bonet E, MartinCastillo B, Del Barco S, Brunet J, Menendez JA (2008) Growth and molecular interactions of the anti-EGFR antibody cetuximab and the DNA cross-linking agent cisplatin in gefitinib-resistant MDA-MB-468 cells: new prospects in the treatment of triplenegative/basal-like breast cancer. Int J Oncol 33:1165-1176

Page DL (2003) Special types of invasive breast cancer, with clinical implications. Am J Surg Pathol 27:832-825

Parikh RR, Housman D, Yang Q, Toppmeyer D, Wilson LD, Haffty BG (2008) Prognostic value of triple-negative phenotype at the time of locally recurrent, conservatively treated breast cancer. Int J Radiat Oncol Biol Phys 72:1056-1063

Perren A, Weng LP, Boag AH, Ziebold U, Thakore K, Dahia PL, Komminoth P, Lees JA, Mulligan LM, Mutter GL, Eng C (1999) Immunohistochemical evidence of loss of PTEN expression in primary ductal adenocarcinomas of the breast. Am J Pathol 155:1253-1260

Pienkowski T, Zielinski CC (2010) Trastuzumab treatment in patients with breast cancer and metastatic CNS disease. Ann Oncol 21:917-924

Rakha EA, El-Sayed ME, Green AR, Lee AH, Robertson JF, Ellis IO (2007) Prognostic markers in triple-negative breast cancer. Cancer 109:25-32

Rakha EA, Elsheikh SE, Aleskandarany MA, Habashi HO, Green AR, Powe DG, El-Sayed ME, Benhasouna A, Brunet JS, Akslen LA, Evans AJ, Blamey R, Reis-Filho JS, Foulkes WD, Ellis IO (2009) Triple-negative breast cancer: distinguishing between basal and nonbasal subtypes. Clin Cancer Res 15:2302-2310

Rhee J, Han SW, Oh DY, Kim JH, Im SA, Han W, Park IA, Noh DY, Bang YJ, Kim TY (2008) The clinicopathologic characteristics and prognostic significance of triple-negativity in node-negative breast cancer. BMC Cancer 8:307

Richardson AL, Wang ZC, De Nicolo A, Lu X, Brown M, Miron A, Liao X, Iglehart JD, Livingston DM, Ganesan S (2006) X chromosomal abnormalities in basal-like human breast cancer. Cancer Cell 9:121-132

Rodriguez-Pinilla SM, Sarrio D, Honrado E, Moreno-Bueno G, Hardisson D, Calero F, Benítez J, Palacios J (2007) Vimentin and laminin expression is associated with basal-like phenotype in both sporadic and BRCA1-associated breast carcinomas. J Clin Pathol 60:1006-1012

Rody A, Karn T, Solbach C, Gaetje R, Munnes M, Kissler S, Ruckhäberle E, Minckwitz GV, Loibl S, Holtrich U, Kaufmann M (2007) The erbB2 + cluster of the intrinsic gene set predicts tumor response of breast cancer patients receiving neoadjuvant chemotherapy with docetaxel, doxorubicin and cyclophosphamide within the GEPARTRIO trial. Breast 16:235-240

Rottenberg S, Jaspers JE, Kersbergen A, van der Burg E, Nygren AO, Zander SA, Derksen PW, de Bruin M, Zevenhoven J, Lau A, Boulter R, Cranston A, O'Connor MJ, Martin NM, Borst P, Jonkers J (2008) High sensitivity of BRCA1-deficient mammary tumors to the PARP inhibitor AZD2281 alone and in combination with platinum drugs. Proc Natl Acad Sci USA 105:17079-17084

Rouzier R, Perou CM, Symmans WF, Ibrahim N, Cristofanilli M, Anderson K, Hess KR, Stec J, Ayers M, Wagner P, Morandi P, Fan C, Rabiul I, Ross JS, Hortobagyi GN, Pusztai L (2005) Breast cancer molecular subtypes respond differently to preoperative chemotherapy. Clin Cancer Res 11:5678-5685 
Saal LH, Holm K, Maurer M, Memeo L, Su T, Wang X, Yu JS, Malmström PO, Mansukhani M, Enoksson J, Hibshoosh H, Borg A, Parsons R (2005) PIK3CA mutations correlate with hormone receptors, node metastasis, and ERBB2, and are mutually exclusive with PTEN loss in human breast carcinoma. Cancer Res 65:2554-2559

Saal LH, Gruvberger-Saal SK, Persson C, Lovgren K, Jumppanen M, Staaf J, Jönsson G, Pires MM, Maurer M, Holm K, Koujak S, Subramaniyam S, Vallon-Christersson J, Olsson H, Su T, Memeo L, Ludwig T, Ethier SP, Krogh M, Szabolcs M, Murty VV, Isola J, Hibshoosh H, Parsons R, Borg A (2008) Recurrent gross mutations of the PTEN tumor suppressor gene in breast cancers with deficient DSB repair. Nat Genet 40:102-107

Samphao S, Eremin JM, El-Sheemy M, Eremin O (2009) Treatment of established breast cancer in post-menopausal women: role of aromatase inhibitors. Surgeon 7:42-55

Sirohi B, Arnedos M, Popat S, Ashley S, Nerurkar A, Walsh G, Johnston S, Smith IE (2008) Platinum-based chemotherapy in triple-negative breast cancer. Ann Oncol 19:1847-1852

Sobin LH, Gospodarowicz MK, Wittekind CH (2009) UICC: TNM classification of malignant tumors. Wiley-Blackwell, Oxford

Sorlie T, Perou CM, Tibshirani R, Aas T, Geisler S, Johnsen H, Hastie T, Eisen MB, van de Rijn M, Jeffrey SS, Thorsen T, Quist H, Matese JC, Brown PO, Botstein D, Eystein Lønning P, BørresenDale AL (2001) Gene expression patterns of breast carcinomas distinguish tumor subclasses with clinical implications. Proc Natl Acad Sci USA 98:10869-10874

Sorlie T, Tibshirani R, Parker J, Hastie T, Marron JS, Nobel A, Deng S, Johnsen H, Pesich R, Geisler S, Demeter J, Perou CM, Lønning PE, Brown PO, Børresen-Dale AL, Botstein D (2003) Repeated observation of breast tumor subtypes in independent gene expression data sets. Proc Natl Acad Sci USA 100:8418-8423

Stratford AL, Habibi G, Astanehe A, Jiang H, Hu K, Park E, Shadeo A, Buys TP, Lam W, Pugh T, Marra M, Nielsen TO, Klinge U, Mertens PR, Aparicio S, Dunn SE (2007) Epidermal growth factor receptor (EGFR) is transcriptionally induced by the Y-box binding protein-1 (YB-1) and can be inhibited with Iressa in basal-like breast cancer, providing a potential target for therapy. Breast Cancer Res 9:R61

Tan AR, Swain SM (2008) Therapeutic strategies for triple-negative breast cancer. Cancer J 14:343-351

Tavassoli FA, Devilee P (2003) World Health Organisation Classification of Tumours. Pathology and Genetics of Tumours of the Breast and Female Genital Organs. IARC Press, Lyon

Tian XS, Cong MH, Zhou WH, Zhu J, Chen YZ, Liu Q (2008) Clinicopathologic and prognostic characteristics of triple-negative breast cancer. Onkologie 31:610-614
Tischkowitz M, Brunet JS, Begin LR, Huntsman DG, Cheang MC, Akslen LA, Nielsen TO, Foulkes WD (2007) Use of immunohistochemical markers can refine prognosis in triple negative breast cancer. BMC Cancer 7:134

Turner NC, Reis-Filho JS, Russell AM, Springall RJ, Ryder K, Steele D, Savage K, Gillett CE, Schmitt FC, Ashworth A, Tutt AN (2007) BRCA1 dysfunction in sporadic basal-like breast cancer. Oncogene 26:2126-2132

Tutt A, Ashworth A (2002) The relationship between the roles of BRCA genes in DNA repair and cancer predisposition. Trends Mol Med 8:571-576

Tutt A, Robson M, Garber JE, Domchek SM, Audeh MW, Weitzel JN, Friedlander M, Arun B, Loman N, Schmutzler RK, Wardley A, Mitchell G, Earl H, Wickens M, Carmichael J (2010) Oral poly(ADP-ribose) polymerase inhibitor olaparib in patients with BRCA1 or BRCA2 mutations and advanced breast cancer: a proof-of-concept trial. Lancet 376:235-244

Veeck J, Ropero S, Setien F, Gonzalez-Suarez E, Osorio A, Benitez J, Herman JG, Esteller M (2010) BRCA1 CpG Island Hypermethylation Predicts Sensitivity to Poly(Adenosine Diphosphate)Ribose Polymerase Inhibitors. J Clin Oncol doi:10.1200/JCO. 2010.30.1010

Viale G, Rotmensz N, Maisonneuve P, Bottiglieri L, Montagna E, Luini A, Veronesi P, Intra M, Torrisi R, Cardillo A, Campagnoli E, Goldhirsch A, Colleoni M (2009) Invasive ductal carcinoma of the breast with the "triple-negative" phenotype: prognostic implications of EGFR immunoreactivity. Breast Cancer Res Treat 116:317-328

von Minckwitz G, Jonat W, Fasching P, du Bois A, Kleeberg U, Luck HJ, Lück HJ, Kettner E, Hilfrich J, Eiermann W, Torode J, Schneeweiss A (2005) A multicentre phase II study on gefitinib in taxane- and anthracycline-pretreated metastatic breast cancer. Breast Cancer Res Treat 89:165-172

von Minckwitz G, Müller B, Loibl S, Blohmer JU, duBois A, Huober J, Kandolf R, Budczies J, Denkert C (2010) PARP is expressed in all subtypes of early breast cancer and is a predictive factor for response to neoadjuvant chemotherapy. Eur J Cancer (Supplements) 8:188

Wang S, Yang H, Tong F, Zhang J, Yang D, Liu H, Cao Y, Liu P, Zhou P, Cheng L, Liu M, Guo J (2009) Response to neoadjuvant therapy and disease free survival in patients with triple-negative breast cancer. Gan To Kagaku Ryoho 36:255-258

Weigelt B, Horlings HM, Kreike B, Hayes MM, Hauptmann M, Wessels LF, de Jong D, Van de Vijver MJ, Van't Veer LJ, Peterse JL (2008) Refinement of breast cancer classification by molecular characterization of histological special types. J Pathol 216:141-150 